\title{
Platelet indices in obstructive sleep apnea: the role of mean platelet volume, platelet distribution widht and plateletcrit
}

\author{
YıImaz BÜLBÜL ${ }^{1}$ \\ Esra AYDIN ÖZGÜR ${ }^{1}$ \\ Asım ÖREM ${ }^{2}$
}

\footnotetext{
${ }^{1}$ Department of Chest Diseases, Faculty of Medicine, Karadeniz Technical University, Trabzon, Turkey

${ }^{1}$ Karadeniz Teknik Üniversitesi Tıp Fakültesi, Göğüs Hastalıkları Anabilim Dalı, Trabzon, Turkey

2 Department of Biochemistry, Faculty of Medicine, Karadeniz Technical University, Trabzon, Turkey

${ }^{2}$ Karadeniz Teknik Üniversitesi Tıp Fakültesi, Biyokimya Anabilim Dalı, Trabzon, Turkey
}

\section{SUMMARY}

Platelet indices in obstructive sleep apnea: the role of mean platelet volume, platelet distribution widht and plateletcrit Introduction: Because studies report controversial findings of mean platelet volume (MPV) and platelet distribution width (PDW), we aimed to investigate platelet indices in patients with obstructive sleep apnea (OSA).

Materials and Methods: One hundred seventy three patients with OSA and 43 control subjects included in analyses. Patients with an apnea-hypopnea index $(A H I) \geq 5$ were considered to have OSA and an AHI $<5$ were considered as control. Platelet indices (MPV, PDW, plateletcrit) were obtained from routine analysis of blood samples using an automated blood cell counter.

Results: Among platelet indices, only PDW was higher in patients with OSA, especially in severe OSA when compared to control group (16.80 \pm 0.56 vs. $16.21 \pm 1.51, p=0.015$ and $16.82 \pm 0.06$ vs.16.21 $\pm 1.51, p=0.014$, respectively). Correlation analysis showed a significant but a weak correlation between the PDW and AHI ( $r=0.161, p=0.018)$ and the PDW and the desaturation index ( $r=0.171, p=0.016$ ). The ROC curve analysis showed that the optimal cut-off value, distinguishing patients with OSA from those in control group, for PDW was 16.62 (sensitivity 57.8\%, specificity 58.1\%, AUROC 0.60, $p=0.042$ ). After the exclusion of patients with comorbid diseases (cardiovascular diseases, diabetes mellitus and chronic inflammatory diseases), we also found weak but a significant correlation between PDW and AHI $(r=0.179, p=0.040)$

Conclusion: In conclusion, among the platelet indices, only PDW was found to be higher in patients with OSA, especially in severe OSA. PDW was also correlated with apnea-hypopnea index and oxygen desaturation index.

Key words: Obstructive sleep apnea, apnea-hypopnea index, mean platelet volume, platelet distribution width, plateletcrit

ÖZET

Obstrüktif uyku apnesinde trombosit indisleri: Ortalama trombosit hacmi, trombosit dağılım genişliği ve plateletcritin yeri

Giriş: Ortalama trombosit hacmi "mean platelet volume (MPV)" ve trombosit dağılım genişliği "platelet distribution with (PDW)" yönünden obstrüktif uyku apnesi (OSA) olan olgularda çelişkili sonuçlar bildirilmesi nedeniyle, bu çalışmada OSA olgularında trombosit indislerinin araştırılması amaçlandı.

Materyal ve Metod: Çalışmaya 173 OSA ve 43 kontrol olgu dahil edildi. Apne-hipopne indeksi (AHi) $\geq 5$ olan olgular OSA hastası, $A H i<5$ olan olgular ise kontrol olarak değerlendirildi. Trombosit indisleri olan MPV, PDW ve plateletcrit değerleri, rutin tam kan sayımı raporlarından (otomatik kan sayımı cihazı ile) elde edildi.

\section{Yazışma Adresi (Address for Correspondence)}

Dr. Yılmaz BÜLBÜL

Karadeniz Teknik Üniversitesi Tıp Fakültesi,

Gögüs Hastalıkları Anabilim Dalı, TRABZON - TURKEY

e-mail: bulbulyilmaz@yahoo.com 
Bulgular: Trombosit indisleri arasında sadece PDW, kontrol grubuna göre OSA olgularında, özellikle ağır OSA olgularında yüksek bulun$d u$ (sırasılyla $16.21 \pm 1.51$ 'e karşın $16.80 \pm 0.56, p=0.015$ ve 16.21 $\pm 1.51^{\prime}$ e karşın $16.82 \pm 0.06, p=0.014$ ). Korelasyon analizinde de PDW ile AHi arasında $(r=0.161, p=0.018)$ ve yine PDW ile desaturasyon indeksi arasında $(r=0.171, p=0.016)$ anlamlı ama zayıf bir ilişki bulundu. ROC analizinde OSA'yı kontrol grubundan ayıran optimal PDW cut-off değeri olarak 16.62 (sensitivite \%57.8, spesifite $\% 58.1$, AUROC 0.60, $p=0.042$ ) bulundu. Komorbid hastalığı olan (kardiyovasküler hastalık, diabetes mellitus ve kronik inflamatuvar hastalıklar) olgular dışlandığında, PDW ve AHi arasındaki anlamlı ilişkinin ( $r=0.179, p=0.040)$ korunduğu saptandı.

Sonuç: Trombosit indisleri arasında sadece PDW'nun OSA olgularında, özellikle ağır olgularda yüksek olduğunu ve yine PDW ile AHI ve desaturasyon indeksi arasında anlamlı korelasyon olduğunu ortaya koymuştur.

Anahtar kelimeler: Obstrüktif uyku apnesi, apne-hipopne indeksi, ortalama trombosit hacmi, trombosit dağılım genişliği, plateletcrit

\section{INTRODUCTION}

Platelet volume indices are known as biomarkers of platelet activation and are reported to be associated with systemic inflammatory responses (1-3). During routine complete blood count analyze, mean platelet volume (MPV) and platelet distribution width (PDW) are the most commonly measured platelet indices. In earlier studies, MPV and PDW were found to be significantly higher in patients with severe obstructive sleep apnea (OSA) when compared to control subjects (4-9). MPV was also reported to be correlated with disease severity and inflammation in patients with obstructive sleep apnea and therefore, it could be used as a marker to predict cardiovascular diseases in patients with OSA (6-8). Moreover continuous positive airway pressure treatment (CPAP) reported to cause a significant decrease in the MPV and PDW values in patients with OSA (10-12). On contrary, some other studies reported no relationship between MPV and OSA, and between PDW and OSA (13-18). Because there are controversies among studies, we aimed to investigate platelet indices in our patients with OSA.

\section{MATERIALS and METHODS}

\section{Subjects and Study Design}

After the approval by the Ethics Committee of Karadeniz Technical University School of Medicine, all adult patients (> 18 years) scheduled for an overnight polysomnography between March 2012-September 2013 and who signed an informed consent were evaluated to participate in this study. Patients' information including demographic characteristics, co-morbid diseases and blood tests etc. were collected for each patient using a standard questionnaire, which was completed by face to face interviews and hospital records. Subjects who have central apnea, acute infectious/inflammatory diseases, malignancy, hematologic diseases, and chronic renal or hepatic diseases were excluded. Cardiovascular disease was identified when the patients had heart failure, coronary artery disease, stroke, or arrhythmia.

\section{Polysomnography and OSA Diagnosis}

The diagnosis of OSA was based on attended full night polysomnography. All polysomnographic variables were recorded on a computer system (ALICE Sleepware, Philips Respironics, Inc, Murrysville, PA, USA), including electroencephalography (F3M2, F4M1, C3M2, C4M1, O1M2, O2M1), bilateral electrooculography, submental electromyography, thoracic and abdominal movements (by inductive plethysmography), oxyhemoglobin saturation (using a pulse oximeter), oronasal airflow (recorded by thermistors and nasal canulla), electrocardiography, snoring microphone, and video monitoring using an infrared video camera. OSA was diagnosed and classified according to the International Classification of Sleep Disorders (19). Patients with an apneahypopnea index $(\mathrm{AHI}) \geq 5$ were considered to have OSA and patients with an $\mathrm{AHI}<5$ were considered as control.

Platelet indices (MPV, PDW, plateletcrit) were obtained from routine analysis of blood samples [in ethylenediaminetetraacetic acid (EDTA) tubes] using an automated blood cell counter (Beckman Coulter LH-750, Hematology Analyzer).

\section{Statistical Analysis}

The Kolmogorov-Smirnov test was used to test for a normal distribution of continuous variables. Data characterized by a normal distribution were expressed as mean \pm standard deviation. Student's t-test was used for the comparison of data because data were distributed normally. Discrete variables were compared using the Chi-square test. Diagnostic 
accuracies of platelet indices for identifying OSA were assessed using the area under the receiver operating characteristic (ROC) curve and area under curve (AUC). The Pearson test was used to assess the correlation between variables. Data were analyzed using SPSS statistical software (version 13.01, serial number 9069728, SPSS Inc., Chicago) and $\mathrm{p}<0.05$ was considered to be significant.

\section{RESULTS}

During the study period, a total of 216 subjects ( 173 patients with OSA and 43 controls) that met the selection criteria were included in the analysis. Patients were classified as mild, moderate and severe OSA in 40 (\%23.1), $45(\% 26.0)$ and 88 (\%50.9) patients respectively. Control group was younger and had lower body mass index (BMI) than the patients with OSA. On contrary, OSA group had higher AHI and oxygen desaturation indexes and comorbid disease, hypertension, than the controls (Table 1).

Platelet indices were not different between control group and the patients with OSA except for PDW (Table 1). PDW was also higher in patients with severe OSA when compared to control group (16.82 \pm 0.06 vs. $16.21 \pm 1.51, p=0.014$ ), however there were no significant differences in mild and moderate
OSA. Correlation analysis showed a significant but a weak correlation between the PDW and $\mathrm{AHI}$ ( $r=$ $0.161, p=0.018$ ). Similarly, there was a significant correlation between the PDW and the oxygen desaturation index $(r=0.171, p=0.016)$. The ROC curve analysis was performed to assess PDW in distinguishing patients with OSA from those in control group. The optimal cut-off value for PDW was 16.62 (sensitivity $57.8 \%$, specificity $58.1 \%$, AUC $0.60, \mathrm{p}=0.042$ ).

After the exclusion of patients with comorbid diseases [cardiovascular diseases, diabetes mellitus and chronic inflammatory diseases (COPD, asthma, collagen vascular diseases etc.)], the remaining 101 patients and 31 controls were re-evaluated and we found a weak, but significant correlation between PDW and AHI ( $r=0.179, p=0.040)$. PDW was also higher in OSA patients, but $p$ value was not statistically significant (Table 2).

\section{DISCUSSION}

Platelets are known to secrete many substances mediating coagulation, inflammation, thrombosis, and atherosclerosis (20). Platelet volume is a marker of platelet function and activation (21). Larger platelets have greater prothrombotic potential

Table 1. Demographic characteristics and platelet indices in patients with obstructive sleep apnea and in the control group

\begin{tabular}{|c|c|c|c|}
\hline & $\begin{array}{l}\text { Control } \\
(n=43)\end{array}$ & $\begin{array}{c}\text { OSA } \\
(n=173)\end{array}$ & $\mathbf{p}$ \\
\hline Age (years) & $42.3 \pm 10.5$ & $53.9 \pm 10.8$ & $<0.0001$ \\
\hline Gender $(M, \%)$ & $18(41.9)$ & $105(60.7)$ & \\
\hline \multicolumn{4}{|l|}{ Comorbidity (n, \%) } \\
\hline Hypertension & $7(16.3 \%)$ & $96(55.8 \%)$ & $<0.0001$ \\
\hline CVD* & $2(4.7 \%)$ & $22(12.8 \%)$ & 0.177 \\
\hline $\mathrm{DM}^{*}$ & $1(2.3 \%)$ & $23(13.3 \%)$ & 0.054 \\
\hline Pulmonary & $10(23.3 \%)$ & $38(22.0 \%)$ & 0.855 \\
\hline Inflammatory diseases & $1(2.3 \%)$ & $6(3.5 \%)$ & 1.000 \\
\hline \multicolumn{4}{|l|}{ Platelet indices (Mean \pm SD) } \\
\hline Platelet count $(/ \mu \mathrm{L})$ & $255348.8 \pm 72000.3$ & $252439.0 \pm 57427.0$ & 0.778 \\
\hline $\mathrm{MPV}^{*}(\mathrm{fL})$ & $8.54 \pm 1.24$ & $8.36 \pm 1.00$ & 0.310 \\
\hline Plateletcrit (\%) & $0.214 \pm 0.049$ & $0.207 \pm 0.044$ & 0.393 \\
\hline $\mathrm{PDW}^{*}(\mathrm{fL})$ & $16.21 \pm 1.51$ & $16.80 \pm 0.56$ & 0.015 \\
\hline \multicolumn{4}{|l|}{ Polysomnography } \\
\hline Apnea-hypopnea index & $1.5 \pm 1.2$ & $38.9 \pm 28.2$ & $<0.0001$ \\
\hline Oxygen desaturatrion index & $3.3 \pm 4.6$ & $31.2 \pm 28.2$ & $<0.0001$ \\
\hline BMI $\left(\mathrm{kg} / \mathrm{m}^{2}\right)$ & $31.1 \pm 6.3$ & $34.3 \pm 7.3$ & 0.014 \\
\hline Epworth sleepiness scale & $6.6 \pm 4.0$ & $7.5 \pm 4.7$ & 0.258 \\
\hline
\end{tabular}


Table 2. Platelet indices in 101 patients with obstructive sleep apnea and 31 control subjects [After the exclusion of patients with comorbid diseases (cardiovascular diseases, diabetes mellitus and chronic inflammatory diseases)]

\begin{tabular}{|lccc|}
\hline Platelet indices $($ Mean $\pm \mathbf{S D})$ & $\begin{array}{c}\text { Control } \\
(\mathrm{n}=31)\end{array}$ & $\begin{array}{c}\text { OSA } \\
(\mathrm{n}=101)\end{array}$ & P \\
\hline Platelet count $(/ \mu \mathrm{L})$ & $246225.8 \pm 60826.9$ & $248485.1 \pm 53494.8$ & 0.843 \\
MPV $(\mathrm{fL})$ & $8.73 \pm 1.32$ & $8.33 \pm 1.06$ & 0.084 \\
Plateletcrit $(\%)$ & $0.210 \pm 0.040$ & $0.201 \pm 0.040$ & 0.295 \\
PDW $(\mathrm{fL})$ & $16.20 \pm 1.54$ & $16.77 \pm 0.58$ & 0.055 \\
\hline MPV: Mean platelet volume, PDW: Platelet distribution width. & & \\
\hline
\end{tabular}

because they are metabolically and enzymatically more active (22). Mean platelet volume, an indicator of platelet activation, is known to have an important role in the pathophysiology of cardiovascular diseases (20-22). Because OSA patients have increased cardiovascular events, studies focused on the role of activated platelets in patients with OSA.

The first study investigating the relationship between mean platelet volume and OSA was performed by Varol et. al. and they showed that MPV was significantly higher in patients with severe OSA (4). The following studies confirmed this preliminary result and also reported that MPV was correlated with $\mathrm{AHI}$ and desaturation index (5-9). These studies were hypothesized that the alterations in MPV may be a confounding factor behind the increased cardiovascular events in OSA $(4,6,7,23)$. One another platelet indices, PDW, was also reported to be higher in non-diabetic patients with severe OSA when compared to control group $(5,9)$. Another study by Kurt et al. reported a meaningful correlation between PDW and AHI (17). Moreover in some studies, it was proposed that treatment with continuous positive airway pressure (CPAP) devices and surgical intervention significantly reduce MPV and PDW values in patients with severe OSA (10-12,24). On contrary, almost similar number of study reported no relationship between MPV and OSA, and between PDW and OSA (13-18).

In our study we investigated all platelet indices including MPV, PDW and plateletcrit and found that only PDW was higher in severe OSA when compared to control group. Other indices including MPV and plateletcrit were not different then the control. As mentioned above, there are several studies reporting no difference in MPV between patients with OSA and control (13-18). The studies reporting difference in MPV, found that MPV was higher only in patients with severe OSA (but not milt-moderate OSA) than the control group $(4-7,9)$. Again, except one study (18), PDW was found to be higher in patients with OSA when compared to control in some studies $(5,9,14)$. Vagdatli et al. reported that PDW may a more specific marker of platelet activation, since it does not increase during simple platelet swelling (25). The plateletcrit is analogous to the hematocrit and reflects the mass of platelets. Because it is associated with the platelet count and MPV, we considered that it may be more valuable than MPV and PDW, however we could not demonstrate a relationship between plateletcrit and $\mathrm{AHI}$ and OSA. There is only one study reporting the role of plateletcrit in OSA and the findings in this study were in accordance to our results (18).

The controversies among studies might be due to sensitive structure of platelets because platelet volume increases significantly in a time-dependent manner (21). Blood sample collection time and their waiting periods in laboratories may be variable in different centers. On the other hand, despite some known factors (diabetes, cardiovascular diseases, inflammatory diseases, antiaggregant and, antihypertensive treatment, etc.) affecting platelet size were excluded in most studies, the standardization of some other factors that may be associated platelet volume (such as lifestyle modification, lipid lowering and diet therapies) might be difficult (26).

In conclusion, among the platelet indices, only PDW was found to be higher in patients with OSA, especially with severe OSA and it was also correlated with apnea-hypopnea index and oxygen desaturation index. This finding confirms that PDW might be a marker of OSAS severity, however we think large, prospective and well-standardized studies are needed to determine the value platelet indices in routine clinical practice. 


\section{REFERENCES}

1. Ozturk ZA, Dag MS, Kuyumcu ME, Cam H, Yesil Y, Yilmaz $N$, et al. Could platelet indices be new biomarkers for inflammatory bowel diseases? Eur Rev Med Pharmacol Sci 2013;17:334- 41 .

2. Küçükbayrak A, Taş T, Tosun M, Aktaş G, Alçelik A, Necati Hakyemez I, et al. Could thrombocyte parameters be an inflammatory marker in the brucellosis? Med Glas (Zenica) 2013;10:35-9.

3. Rondina MT, Brewster B, Grissom CK, Zimmerman GA, Kastendieck $D H$, Harris $E S$, et al. In vivo platelet activation in critically ill patients with primary 2009 influenza A (H1N1) Chest 2012;141:1490-5.

4. Varol E, Ozturk O, Gonca T, Has M, Ozaydin M, Erdogan $D$, et al. Mean platelet volume is increased in patients with severe obstructive sleep apnea. Scand I Clin Lab Invest 2010;70:497-502.

5. Nena E, Papanas N, Steiropoulos P, Zikidou P, Zarogoulidis P, Pita $E$, et al. Mean platelet volume and platelet distribution width in non-diabetic subjects with obstructive sleep apnoea syndrome: new indices of severity? Platelets 2012;23:447-54.

6. Kanbay A, Tutar N, Kaya E, Buyukoglan H, Ozdogan N, Oymak FS, et al. Mean platelet volume in patients with obstructive sleep apnea syndrome and its relationship with cardiovascular diseases. Blood Coagul Fibrinolysis 2013;24:532-6.

7. Karakaş MS, Altekin RE, Baktır AO, Küçük M, Çilli A, Yalçınkaya S. Association between mean platelet volume and severity of disease in patients with obstructive sleep apnea syndrome without risk factors for cardiovascular disease. Arch Turk Soc Cardiol 2013;41:14-20.

8. Akyol S, Çörtük M, Baykan AO, Kiraz K, Börekçi A, Şeker T, et al. Mean platelet volume is associated with disease severity in patients with obstructive sleep apnea syndrome. Clinics (Sao Paulo) 2015;70:481-5.

9. Zheng X, Hao R, Fu W. Analysis the relationship of mean platelet volume and obstructive sleep apnea and hypopnea syndrome. Lin Chung Er Bi Yan Hou Tou Jing Wai Ke Za Zhi 2015;29:517-9.

10. Varol E, Ozturk O, Yucel H, Gonca T, Has M, Dogan A, et al. The effects of continuous positive airway pressure therapy on mean platelet volume in patients with obstructive sleep apnea. Platelets 2011;22:552-6.

11. Sökücü SN, Ozdemir C, Dalar L, Karasulu L, Aydın S, Altın S. Complete blood count alterations after six months of continuous positive airway pressure treatment in patients with severe obstructive sleep apnea. I Clin Sleep Med 2014; 10:873-8.

12. Esen E, Özdoğan F, Özel HE, Yılmaz Z, Yüce T, Başer S, et al. Mean platelet volume play a role in disease severity in patients with obstructive sleep apnea syndrome? Kulak Burun Bogaz Ihtis Derg 2015;25:343-5.
13. Atan D, Sazak Kundi FC, Özcan KM, Dere H. The relationship between platelet count and mean platelet volume with obstructive sleep apnea syndrome. Kulak Burun Bogaz Ihtis Derg 2015;25:289-94.

14. Topçuoğ/u ÖB, Afşar GÇ, Saraç S, Oruç Ö, Kuyucu T. In the abscence of co-morbidities mean platelet volume is not a severity indicator in OSAS. Eur J Gen Med 2016;13:134-8.

15. Akyüz A, Akkoyun DÇ, Oran $M$, Değirmenci $H, A l p R$. Mean platelet volume in patients with obstructive sleep apnea and its relationship with simpler heart rate derivatives. Cardiol Res Pract 2014;2014:454701.

16. Sökücü SN, Özdemir C, Dalar L, Karasulu L, Aydın Ş, Altın S. Is mean platelet volume really a severity marker for obstructive sleep apnea syndrome without comorbidities? Pulmonary Medicine 2014;ID754839:1-7.

17. Kurt ÖK, Yildiz N. The importance of laboratory parameters in patients with obstructive sleep apnea syndrome. Blood Coagul Fibrinolysis 2013:24:371-4.

18. Sak ZHA, Yalçın F, Kurnaz AÖ, Gencer M, Eser I, Günay Ş. Assessment of mean platelet volume in patients with severe obstructive sleep apnea. I Harran University Medical Faculty 2015;12:206-10.

19. American Academy of Sleep Medicine. International classification of sleep disorders, $2^{\text {nd }}$ ed. Diagnostic and coding manual. Westchester, Illinois: American Academy of Sleep Medicine, 2005.

20. Chu SG, Becker RC, Berger PB, Bhatt DL, Eikelboom JW, Konkle $B$, et al. Mean platelet volume as a predictor of cardiovascular risk: a systematic review and meta-analysis. J Thromb Haemost 2010;8:148-56.

21. Bath PM, Butterworth RJ. Platelet size: measurement, physiology and vascular disease. Blood Coagul Fibrinolysis 1996; 7:157-61.

22. Tsiara S, Elisaf $M$, Jagroop IA, Mikhailidis DP. Platelets as predictors of vascular risk: Is there a practical index of platelet activity? Clin Appl Thromb Hemost 2003;9:177-90.

23. Saygin M, Ozturk O, Ozguner MF, Akkaya A, Varol E. Hematological parameters as predictors of cardiovascular disease in obstructive sleep apnea syndrome patients. Angiology 2016;67:461-70.

24. Günbey E, Karabulut I, Karabulut H, Zaim M. Impact of multilevel surgical treatment on mean platelet volume inpatients with obstructive sleep apnea syndrome. J Craniofac Surg 2015;26:1287-9.

25. Vagdatli E, Gounari E, Lazaridou E, Katsibourlia E, Tsikopoulou F, Labrianou I. Platelet distribution width: a simple, practical and specific marker of activation of coagulation. Hippokratia 2010;14:28-32.

26. Gasparyan AY, Ayvazyan L, Mikhailidis DP, Kitas GD. Mean platelet volume: a link between thrombosis and inflammation? Curr Pharm Des 2011;17:47-58. 